\title{
Effect of supplementation of broiler diets with essential oils on growth performance, antioxidant status, and general health
}

\author{
Nancy Moustafa, Abeer Aziza*, Ola Orma, Tarek Mohamed \\ Department of Nutrition and Nutritional Deficiency Diseases, Faculty of Veterinary Medicine, Mansoura University
}

\section{ARTICLE HISTORY \\ ABSTRACT}

\section{Received: 27.02 .2020}

Revised: 23.03 .2020

Accepted: 29.03 .2020

Address correspondence to Abeer Aziza; Tel: +2-01205074978; E-mail: E-mail: abeeraziza@gmail.com

\begin{abstract}
Objective: To evaluate the effect of dietary supplementation of essential oils (EOs) of thyme, clove, and cinnamon to broiler chickens on growth performance, serum metabolites, and tissue lipid peroxidation and antioxidants enzyme activities.

Design: Randomized controlled study

Animals: One hundred-eighty, one-day-old Cobb broiler chicks were randomly allocated into 4 treatment groups ( 3 replicates, 15 chicks each). Broilers were reared in deep litter system - pens for 6 weeks of age.

Procedures: The control group was fed on corn-soybean basal control diets (starter, grower and finisher) without EOs supplementation. In addition to the basal-control diets, the 3 experimental broiler groups were supplemented with thyme oil ( $2^{\text {nd }}$ group), clove oil ( $3^{\text {rd }}$ group) or cinnamon oil ( $4^{\text {th }}$ group) at $100 \mathrm{mg} / \mathrm{kg}$. Blood, liver and muscle (breast) samples were collected from 3 broilers of each replicate at 40 days of age for measurement of serum metabolites, malondialdehyde (MDA), and antioxidant enzyme activities (liver catalase (CAT), superoxide dismutase (SOD) and glutathione peroxidase (GSH-Px).

Results: The broiler chickens fed on the diets supplemented with $100 \mathrm{mg} / \mathrm{kg}$ cinnamon oil had significantly higher body weight, body weight gain and feed intake, followed by broiler chickens fed on the diets supplemented with $100 \mathrm{mg} / \mathrm{kg}$ thyme and $100 \mathrm{mg} / \mathrm{kg}$ clove oils in comparison with control group, which was showed the lowest growth performance. Supplementation with EOs significantly improved feed conversion ratio (FCR), with increased liver CAT, SOD, GSH-Px activities, as well as serum level of high density lipoprotein (HDL) in comparison with control group, also, it induced a significant decrease in serum levels of cholesterol, triglycerides, low density lipoprotein (LDL), as well as both liver and muscle tissue lipid peroxidation (MDA).

Conclusion and clinical relevance: The present results indicate that dietary supplementation of EOs (thyme, clove, and cinnamon) at $100 \mathrm{mg} / \mathrm{kg}$ resulted in significantly higher body weight, body weight gain, improved FCR, reduced serum cholesterol, triglycerides and LDL. Also, reduced lipid peroxidation in liver and muscle, and improved antioxidants status of broiler chickens.
\end{abstract}

Keywords: Essential oils, Growth performance, Serum metabolites, Antioxidants, Broilers.

\section{INTRODUCTION}

The excessive use of antibiotics as growth promoters in animal production may potentially affect human health. This may result in the residues, with subsequent proliferation of antibiotics-insensitive bacteria [1]. Essential oils recently have been used as an alternatives to antibiotics in animal production for improving growing performance parameters and the quality characteristics of the derived products including meat, milk and eggs [2]. Essential oils derived mainly from spices and herbs and their pure compounds have been shown to have antimicrobial activity, antioxidants, hypocholesterolemic, and digesting effects $[3,4]$. The supplementation of essential oils to poultry diets have shown to stimulate the production of endogenous enzymes and thus enhances feed utilization [4]. It has been also shown that the dietary incorporation of herbs and their associated essential oils may provide beneficial effects on poultry performance and health due to the antimicrobial activity of their phytochemical components [5]. However, other 
studies have not found positive effects of herbs and their related essential oils [6].

Oxidation of lipids and free radicals' production are natural processes that destroy the membrane structure, disturb transport processes and cause losses in the function of the cell organelles [7]. Synthetic antioxidants as (butylated hydroxyanisole (BHA), butylated hydroxytoluene (BHT) are traditionally used for preventing lipid peroxidation but during the last decades, there is interesting in employing antioxidants from natural sources due to consumer preference for natural occurring ingredients and concerns about the possible toxic effects of synthetic antioxidants [8]. Essential oils are rich sources of natural antioxidants, such as the phenolic compounds and due their high redox properties and chemical structure have the ability to neutralize free radicals, chelate transitional metals and quench singlet and triplet oxygen by delocalization or decomposition of peroxides [9].

Thymol is the main constituent of thyme's volatile oils which form 20-55\% of its extract. The major derived components of thyme (Thymus vulgaris L.) plant are thymol and carvacrol, the phenolic compounds which have shown antioxidant, anticoccidial and antifungal activities [10]. It had been shown that dietary supplementation of thyme oil $(1 \mathrm{~g} / \mathrm{kg}$ diet) had positive effects on broiler chickens performance [11]. Also, Several studies have reported the beneficial effects of thyme in poultry nutrition $[12,13,14]$.

Clove (Syzygium arimaticum), and its essential oil, is one of the plant extracts that has been found to be effective in improving poultry growth performance, control some intestinal pathogens, antiseptic activity and as digestion stimulation. It also provides strong antimicrobial antifungal, antiinflammatory, anesthetic, anti-carcinogenic, antiparasitic and antioxidant effects [15]. Also, cinnamon (Cinnamomum zeylanicum), one of the oldest medicinal plants, can provide similar effects as Clove [16].

Therefore, the present study was delineated to evaluate the effect of dietary supplementation of thyme, clove, or cinnamon oils on growth performance, serum metabolites, lipid peroxidation and antioxidants activities in broiler chickens.

\section{MATERIALS AND METHODS}

\subsection{Experimental birds and management}

A total of one hundred eighty Cobb broiler chicks (Cobb 500) of one-day old were obtained from commercial hatchery ((El Dakahlia Poultry Company) and randomly allocated into four equal groups (each has three replicates,15 chicks/ replicate). During the first 3 days of the age, the brooding temperature was maintained at 35 to $32{ }^{\circ} \mathrm{C}$ with a constant lighting ( 24 hours/day) then the room temperature was decreased by $1-2^{\circ} \mathrm{C}$ every 2 days to be $22-25^{\circ} \mathrm{C}$ by the beginning of the third week of age. Then after, during the $4^{\text {th }}$ to the $6^{\text {th }}$ week of age, the pens were naturally exposed to the atmospheric ambient temperature and ventilation and at night the light was continuously maintained.

\subsection{Experimental diets}

Diets were formulated to meet the nutrient requirements of Cobb broiler chickens. Feed ingredients, chemical composition and nutrition value of the diets are presented in (Table 1).The control group, broiler chicks were fed on cornsoybean meal basal control diets (starter, grower and finisher). However, essential oils (thyme, clove and cinnamon) were supplemented at $100 \mathrm{mg} / \mathrm{kg}$ diet for the second, third and fourth experimental group, respectively. Diets and water were provided ad libitum during whole experimental period.

\subsection{Growth performance}

The broiler chicks were weighed individually at the beginning of the experimental period (initial body weight (IBW), weekly, and at day 40 of age (Final body weight, FBW) to calculate body weight gain (BWG). Feed conversion ratio (FCR) was also calculated as $\mathrm{kg}$ feed per kg BWG.

\subsection{Samples collection}

At the end of the experiment (day 40 of age), three broiler chickens from each replicate were randomly selected for sampling. The blood samples were drawn from wing vein into plain test tubes and kept at room temperature for $20 \mathrm{~min}$ to allow clotting, and then left in the refrigerator for $4 \mathrm{~h}$. carefully the clear serum was then separated by centrifugation at 3000 rpm for $10 \mathrm{~min}$ and stored at $-20{ }^{\circ} \mathrm{C}$ until further selected biochemical parameters measurement. After blood sampling birds were slaughtered, and one gram samples from the liver and breast muscle were excised, washed in an ice-cold saline buffer (20 mM Tris- $\mathrm{HCl}, 0.14 \mathrm{M} \mathrm{NaCl}$ buffer, $\mathrm{pH}$ 7.4) and homogenized in ice-cold phosphate buffered saline (PBS) (pH 7.4). The homogenates were centrifuged at $4{ }^{\circ} \mathrm{C}$ for $15 \mathrm{~min}$ at $3000 \mathrm{rpm}$. The supernatants were then carefully collected and stored at $-20{ }^{\circ} \mathrm{C}$ for estimation of oxidative stress and antioxidant biomarkers [17].

\subsection{Serum biochemical analysis}

The serum samples were analysed spectrophotometrically (5010 photometer, BM Co., Berlin, Germany) for determination of alanine aminotransferase (ALT) and aspartate aminotransferase (AST) activities. Serum total protein (TP) and albumin (Alb) were evaluated using Stanbio Laboratory (Boerne, TX, USA) kits. Globulin (Glob) concentration in serum was calculated by subtracting albumin from total proteins. The creatine was assayed by using commercial test kits (Spinreact, Sant Esteve d'en Bas, Spain). The kits manufactured by Spinreact (Sant Esteve d'en Bas, Spain) were also used for the determination of cholesterol, triglycerides (TG) and highdensity lipoprotein cholesterol (HDL-C) concentrations. 


\subsection{Oxidative stress and antioxidant markers in tissue homogenates}

The malondialdehyde (MDA), reduced glutathione (GSH) contents, catalase (CAT) and superoxide dismutase (SOD) activities were determined in liver and muscle homogenates spectrophotometrically by enzymatic colorimetric method using commercial Bio-diagnostic (Giza, Egypt) kits, according to the supplier's instructions.

\subsection{Statistical Analysis}

The data were subjected to statistical analysis of variance (ANOVA) using one way test to evaluate the influence of dietary supplementation of essential oils from either thyme, clove or cinnamon on growth performance, serum metabolites, and tissue lipid peroxidation and antioxidants enzyme activities of broiler chickens (Cobb 500). Data were analyzed using statistical SPSS v20 (SPSS Inc., Chicago, IL, USA). Differences among dietary treatments were compared using Duncan's test and significant was declared at $(p<0.05)$.

\section{RESULTS}

The results showed a significant $(p<0.05)$ increase in final body weight (FBW), body weight gain (BWG), feed intake, and improvement of feed conversion ratio (FCR) of broiler chickens fed diet supplemented with EOs of thyme, clove and cinnamon at $100 \mathrm{mg} / \mathrm{kg}$ diet when compared to control group (Table 2). The best significant performance $(p<0.05)$ parameters were demonstrated in the broiler chickens fed diet supplemented with cinnamon oil as compared to those supplemented with thyme or clove oils.
The influence of dietary supplementation of EOs of thyme, clove, and cinnamon on serum metabolites parameters are summarized in (Table 3). There were significantly decreased in serum level of ALT, AST, cholesterol, triglycerides, and LDL of the broiler chickens fed diets supplemented with EOs in comparison with control group. Also, serum level of HDL and total protein are significantly increased in the broiler chickens fed the diet supplemented with EOs especially cinnamon oil compared to control group.

Table 4 indicates the effect of dietary supplementation of EOs on liver and muscle lipid peroxidation and antioxidant enzyme activities. MDA values as indicator for lipid peroxidation in both liver and muscle tissue of broiler chickens fed diets supplemented with EOs significantly decreased in comparison with control group. Regarding to antioxidant enzymes activity in liver and muscle tissue, there was no significant difference of liver CAT activity between the experimental groups. However, muscle tissue CAT activity was higher in the chickens group supplemented with cinnamon oil group. There were no significant differences in the activity of SOD, CAT and GSH enzyme activities in liver tissue between the control group and chicken groups fed diets supplemented with EOs of thyme or clove. Also, in muscle tissue enzyme activity of SOD and CAT were similar. The data showed that EOs supplementation with thyme, clove or cinnamon (at $100 \mathrm{mg} / \mathrm{kg}$ ) significantly increased GSH activity in muscle tissue, which would indicate improved muscle quality. Clearly dietary supplementation with cinnamon oil significantly decrease lipid peroxidation and increased activity of antioxidant enzymes in both liver muscle tissues (Table 4).

Table 1. Ingredient composition percentage and nutritive value of experimental diets.

\begin{tabular}{|c|c|c|c|}
\hline \multicolumn{4}{|c|}{ Experimental diets } \\
\hline Ingredients (\%) & Starter & Grower & Finisher \\
\hline Corn, yellow & 59.39 & 63.41 & 69.17 \\
\hline Soybean meal $48 \%$ CP & 30.00 & 26.83 & 18.92 \\
\hline Corn gluten $60 \% \mathrm{CP}$ & 4.53 & 3 & 6.30 \\
\hline Soybean oil & 2.60 & 3.4 & 2.60 \\
\hline Lime stone & 1.90 & 1.83 & 1.74 \\
\hline Dicalcium phosphate & 0.41 & 0.33 & 0.20 \\
\hline Common salts & 0.30 & 0.30 & 0.30 \\
\hline Min.\& Vit. Premix** & 0.25 & 0.25 & 0.25 \\
\hline DL Lysine HCL & 0.39 & 0.35 & 0.38 \\
\hline DL Methionine & 0.13 & 0.15 & 0.08 \\
\hline L-threonine & 0.08 & 0.08 & 0.06 \\
\hline L-Valine & 0.02 & 0.02 & 0 \\
\hline \multicolumn{4}{|l|}{ Chemical Composition (\%) } \\
\hline Calculated CP & 21.50 & 19.50 & 18.50 \\
\hline Calculated ME (Kcal/kg) & 3034 & 3107 & 3180 \\
\hline Analyzed CP* & 21.32 & 19.40 & 18.41 \\
\hline Analyzed EE* & 5.40 & 5.82 & 5.80 \\
\hline Analyzed Ash* & 5.97 & 6.36 & 5.00 \\
\hline $\mathrm{Ca}$ & 0.9 & 0.84 & 0.76 \\
\hline Available P & 0.46 & 0.43 & 0.38 \\
\hline
\end{tabular}


Table 2. Effect of dietary supplementation of essential oils (thyme, clove, cinnamon) on growth performance of broiler chickens (6 wks period) (Means \pm standard error).

\begin{tabular}{lllll} 
& \multicolumn{4}{c}{ Experimental diets $^{1}$} \\
\cline { 2 - 5 } Parameters & Control & Thyme oil & Clove oil & Cinnamon oil \\
\hline IW, g & $43.00 \pm 1.50$ & $42.67 \pm 2.00$ & $43.44 \pm 2.7$ & $43.00 \pm 3.16$ \\
FBW, g & $2083 \pm 15.94^{\mathrm{b}}$ & $2257.5 \pm 15.24^{\mathrm{a}}$ & $2342 \pm 29.22^{\mathrm{a}}$ & $2412 \pm 35.61^{\mathrm{a}}$ \\
BWG, g & $2040 \pm 15.94^{\mathrm{b}}$ & $2214.83 \pm 15.24^{\mathrm{a}}$ & $2298.56 \pm 29.22^{\mathrm{a}}$ & $2369 \pm 35.61^{\mathrm{a}}$ \\
Feed consumption, g & $3713 \pm 100^{\mathrm{b}}$ & $3765.2 \pm 98.5^{\mathrm{b}}$ & $3930.54 \pm 112.5^{\mathrm{a}}$ & $3908.85 \pm 90.67^{\mathrm{a}}$ \\
FCR & $1.8 \pm 0.026^{\mathrm{a}}$ & $1.68 \pm 0.015^{\mathrm{b}}$ & $1.76 \pm 0.02^{\mathrm{b}}$ & $1.68 \pm 0.04^{\mathrm{b}}$
\end{tabular}

${ }^{1}$ experimental diets were corn-soybean based diet supply nutrients to meet Cobb requirement, control group without supplementation of essential oils, other experimental groups supplemented with either $100 \mathrm{mg} / \mathrm{kg}$ of thyme, clove, or cinnamon oils.

abc Means in the row with different letters are significantly different at $(p<0.05)$

Table 3. Effect of dietary supplementation of essential oils (thyme, clove, cinnamon) on serum metabolites of broiler chickens at the end of the experimental period (40 days) (Means \pm standard error).

\begin{tabular}{lllll} 
& \multicolumn{4}{c}{ Experimental diets $^{1}$} \\
\cline { 2 - 5 } Parameters & Control & Thyme oil & Clove oil & \multicolumn{1}{c}{ Cinnamon oil } \\
ALT (U/l) & $40.33 \pm 1.7^{\mathrm{a}}$ & $31.00 \pm 2.6^{\mathrm{b}}$ & $29.00 \pm 3.6^{\mathrm{b}}$ & $26.00 \pm 2.5^{\mathrm{b}}$ \\
AST (U/l) & $66.33 \pm 5.45^{\mathrm{a}}$ & $29.00 \pm 2.8^{\mathrm{b}}$ & $37.00 \pm 2.3^{\mathrm{b}}$ & $28.33 \pm 2.02^{\mathrm{b}}$ \\
Total protein (g/dl) & $6.90 \pm 0.45^{\mathrm{b}}$ & $7.50 \pm 0.72^{\mathrm{ab}}$ & $7.00 \pm 0.30^{\mathrm{b}}$ & $8.50 \pm 0.55^{\mathrm{a}}$ \\
Albumin (g/dl) & $4.20 \pm 0.26$ & $4.50 \pm 0.32$ & $4.40 \pm 0.50$ & $4.90 \pm 0.10$ \\
Globulin (g/dl) & $2.70 \pm 0.20^{\mathrm{a}}$ & $3.00 \pm 0.17^{\mathrm{a}}$ & $2.60 \pm 0.46^{\mathrm{ab}}$ & $3.60 \pm 0.28^{\mathrm{a}}$ \\
Creatine (mg/dl) & $1.00 \pm 0.05^{\mathrm{a}}$ & $1.03 \pm 0.088^{\mathrm{a}}$ & $1.06 \pm 0.12^{\mathrm{a}}$ & $0.73 \pm 0.033^{\mathrm{b}}$ \\
Cholesterol (mg/dl) & $170.66 \pm 19.59^{\mathrm{a}}$ & $135.00 \pm 3.78^{\mathrm{b}}$ & $141.00 \pm 4.35^{\mathrm{b}}$ & $117.00 \pm 5.13^{\mathrm{b}}$ \\
Triglycerides (mg/dl) & $90.33 \pm 4.05^{\mathrm{a}}$ & $80.00 \pm 1.52^{\mathrm{a}}$ & $78.00 \pm 2.5^{\mathrm{ab}}$ & $48.00 \pm 3.21^{\mathrm{c}}$ \\
HDL-C (mg/dl) & $57.66 \pm 5.23^{\mathrm{b}}$ & $65.00 \pm 3.78^{\mathrm{a}}$ & $59.00 \pm 2.08^{\mathrm{ab}}$ & $70.66 \pm 5.04^{\mathrm{a}}$ \\
LDL-C (mg/dl) & $107.66 \pm 5.89^{\mathrm{a}}$ & $53.33 \pm 5.84^{\mathrm{b}}$ & $66.00 \pm 3.05^{\mathrm{b}}$ & $39.66 \pm 3.84^{\mathrm{c}}$
\end{tabular}

${ }^{1}$ experimental diets were corn-soybean based diet supply nutrients to meet Cobb requirement, control group without supplementation of essential oils, other experimental groups supplemented with either $100 \mathrm{mg} / \mathrm{kg}$ of thyme, clove, or cinnamon oils.

abc Means in the row with different letters are significantly different at $(p<0.05)$.

Table 4. Effect of dietary supplementation of essential oils of thyme, clove and cinnamon on muscle and liver tissue lipid peroxidation and antioxidant enzymes activity of broiler chickens (Means \pm standard error).

\begin{tabular}{|c|c|c|c|c|}
\hline \multirow{2}{*}{ Parameters } & \multicolumn{4}{|c|}{ Experimental diets 1} \\
\hline & Control & Thyme oil & \multicolumn{2}{|c|}{ Cinnamon oil } \\
\hline \multicolumn{5}{|l|}{ Liver tissue } \\
\hline MDA (nmol/g) & $37.03 \pm 4.38^{\mathrm{a}}$ & $34.50 \pm 3.68^{\mathrm{a}}$ & $25.56 \pm 4.48^{\mathrm{ab}}$ & $18.03 \pm 1.08^{b}$ \\
\hline $\operatorname{SOD}(\mathrm{u} / \mathrm{g})$ & $371.00 \pm 24.00^{b}$ & $471.00 \pm 41.29^{\mathrm{ab}}$ & $415.00 \pm 27.61^{b}$ & $529.33 \pm 28.42^{\mathrm{a}}$ \\
\hline CAT (u/g) & $9.60 \pm 1.24^{b}$ & $12.20 \pm 0.81^{\mathrm{a}}$ & $9.43 \pm 1.20^{\mathrm{b}}$ & $12.06 \pm 0.99^{a}$ \\
\hline $\mathrm{GSH}(\mathrm{mg} / \mathrm{g})$ & $2.20 \pm 0.23^{b}$ & $2.76 \pm 0.37^{b}$ & $2.10 \pm 0.17^{b}$ & $4.26 \pm 0.52^{\mathrm{a}}$ \\
\hline \multicolumn{5}{|l|}{ Muscle tissue } \\
\hline $\mathrm{MDA}(\mathrm{nmol} / \mathrm{g})$ & $40.36 \pm 1.33^{a}$ & $27.13 \pm 3.90^{\mathrm{b}}$ & $23.96 \pm 5.00^{b}$ & $20.90 \pm 1.40^{\mathrm{b}}$ \\
\hline SOD $(u / g)$ & $399.00 \pm 17.67^{b}$ & $466.33 \pm 25.11^{b}$ & $407.00 \pm 19.75^{b}$ & $555.33 \pm 37.47^{a}$ \\
\hline CAT (u/g) & $8.10 \pm 1.05^{b}$ & $9.83 \pm 1.29^{a b}$ & $9.76 \pm 0.89^{a b}$ & $11.83 \pm 1.24^{a}$ \\
\hline $\mathrm{GSH}(\mathrm{mg} / \mathrm{g})$ & $2.46 \pm 0.47^{c}$ & $3.83 \pm 0.18^{b}$ & $3.86 \pm 0.28^{b}$ & $5.23 \pm 0.43^{a}$ \\
\hline
\end{tabular}




\section{DISCUSSION}

In the present study, the growth performance parameters are significantly improved in the broiler chickens fed diets supplemented with EOs. These results were consistent with the results of [5] who found that cinnamon supplementation to the diet of broilers improved their growth performance. Moreover, Ebrahimi et al. [18] found that the body weight of the broilers was significantly higher on feeding a diet supplemented with cinnamon oil. Also, our results are in agreement with that of other researchers [19-23].

Regarding the dietary thyme oil supplementation, our results are in agreement with Wade et al. [24] who showed that dietary supplementation of thyme oil at level of $100 \mathrm{mg} / \mathrm{kg}$ of diet of broiler chicken diets significantly increased $(p<0.05)$ BW, BWG and improved FCR. Also, these results are consistent with other studies [12-14]. Even more, it had been shown that dietary supplementation of 100 and $200 \mathrm{mg} / \mathrm{kg}$ of clove oil for broiler chickens had the greater performance values compared to broilers fed un supplemented diet [25]. With the same concept, clove oil has been found to be effective in improving broiler chicken growth performance in previous experiments $[14,26-28]$. The positive effect of clove oil on growth performance could be due to the active materials in clove (ugeonol) that are considered as digestion stimulatory factors, in addition to their antimicrobial activity against bacteria found in intestine [29]. Also, it has been reported that clove oil improve of trace minerals necessary for protein and carbohydrate metabolism, and the synthesis of fatty acid and cholesterol and contain in lesser amounts, omega 3 fatty acid so these could be improve broiler performance [30]. The improvement of growth performance (BWG and FCR) of the broiler chickens due to dietary supplementation with thyme oil and cinnamon oil could be attributed to stimulation of secretion of digestive enzymes, Lee et al. [5] reported that thymol and cinnamaldehyde at the level of $100 \mathrm{ppm}$ stimulate secretion of pancreatic enzyme such as amylase, lipase, trypsin and chymotrypsin in broiler chickens and induce to increase their performance. Moreover, the improvement of BWG and FCR could be due to the active materials (Cinnamaldehyde and ugenol) found in cinnamon which causing greater efficiency in the utilization of feed, resulting in enhanced growth [21]. Also, positive effect of cinnamon oil on growth performance may be due to antimicrobial effects on the pathogenic bacteria and fungi in digestive systems [31]. In addition, the positive effect of thyme oil is attributed to the increase of digestive enzymes and improve nutrients utilization through the enhanced liver function [32]. Moreover, it has been reported that essential oils blocked effect of pathogens in the digestive system, improved feed intake, and feed conversion ratio [33]. However, other authors did not find positive effect of body weight gain or feed efficiency with application of EOs or its main components [11, 34-36].

The dietary supplementation of EOs to the broiler chickens significantly decreased serum cholesterol level. The cholesterol-lowering property of EOs constituents has been attributed to suppressing of 3-hydroxy-3methylglutaryl coenzyme A reductase, the enzyme that is considered to be rate limiting in cholesterol synthesis [37]. On contrary to our result, dietary clove oil supplementation has not affected serum levels of cholesterol, triglyceride, HDL, LDL and VLDL of broilers [38]. Also, it has been shown that plasma total cholesterol, triglycerides and HDL were not affected by dietary EOs (thyme, clove, cinnamon) inclusion to broilers diets [14]. Moreover, Lee et al. [6] did not find any hypocholesterolemic effects for the active items as thymol, cinnamaldehyde.

The liver plays an important role in metabolic processes, and the metabolic activities of the liver are important for the normal functioning of cellular events. Serum AST and ALT are indicators of normal liver function [39]. With the same concept of our results, Faix et al. [16] reported that ALT was significantly reduced in chickens fed diets supplemented with $0.05 \%$ and $0.025 \%$ of cinnamon oil. Also, dietary supplementation of different levels of thyme oil to broiler chickens diets significantly decreased the plasma AST [40].

It has been reported that plasma total protein and albumin are the main transport proteins in avian species, and they reflect the avian nutritional condition [41]. The increase in serum content of protein suggested the capacity of EOs to improve digestion and absorption of proteins as previously reported by Bento et al. $[42,43]$ allowing a better use of protein in broiler chicken and thus an improvement of the weight gain.

In the present study, malondialdehyde (MDA) levels, an indicator of lipid peroxidation and oxidative damage were significantly decreased in liver and muscle tissue of broiler chickens fed on EOs supplementation diets. The activities of the antioxidant enzymes CAT (catalase) and SOD (superoxide dismutase), which protect tissues against oxidation, and the enzyme GSH-Px (reduced glutathione), which protects intracellular lipids against peroxidation increased with dietary supplementation of EOs (Table 4). In accordance with our results, increased concentration of glutathione peroxidase (GSH-Px) and a reduced level of MDA of broiler chickens fed diet supplemented with cinnamon oil had been reported [44]. The antioxidant properties of cinnamon oil and its action could be mainly attributed to cinnamaldehyde and eugenol, substances that react with lipid and hydroxyl radicals converting them into stable products through their hydrogen donating ability [45]. In addition, it has been shown that the thymol and carvacrol contents of thyme oil significantly reduces lipid peroxidation in tissues [46]. Similarly, dietary supplementation of thyme oil 
significantly increased liver CAT, SOD and GSH-Px activities and serum CAT and GSH-Px activities, and significantly reduced both liver and serum lipid peroxidation (MDA levels) of broiler chickens [47]. Also, Fki et al. [48] reported that Phenolic compounds of EOs increased the activity of CAT, which in turn detoxifies hydrogen peroxide and converts lipid hydroperoxides to nontoxic substances. In addition, Hsu and Liu [49] postulated that the protective role of EOs could be attributed to its antioxidative defense mechanism through the induction of antioxidant enzyme activities. Furthermore, Petrovic et al. [50] reported that cloves essential oil had strongest antioxidant activity among herb extracts.

\section{Conclusion}

Collectively, from the results of the present study it could be concluded that supplementation of broiler diets with EOs of thyme, clove and cinnamon at $100 \mathrm{mg} / \mathrm{kg}$ could improve growth performance, as well as decrease lipid peroxidation of liver and muscle tissue. They could also improve the activity of antioxidant enzymes (SOD, CAT and GSH) in liver and muscle tissue with reducing of cholesterol, triglycerides and LDL. However, cinnamon oil supplementation appears the most effective among the tested EOs.

\section{Acknowledgement}

\section{Conflict of interest}

The authors declare that they have no conflict of interest.

\section{Research ethics committee permission}

All methods used in the study were performed in accordance with the ethical guidelines and recommendations of the Research Ethics Committee, Faculty of Veterinary Medicine, Mansoura University.

\section{Authors' contribution}

N. M designed the model and analyzed the data; A.E carried out the experimental works. O. O drafting the manuscript; T. M. revised the manuscript.

\section{REFERENCES}

[1] Schwarz S, Kehrenberg C, Walsh T. Use of antimicrobial agents in veterinary medicine and food animal production. Int J Antimicrob Agents. 2001;17:431-7. https://doi.org/10.1016/S0924-8579(01)00297-7

[2] Simitzis P, Symeon G, Charismiadou M, Ayoutanti A, Deligeorgis S. The effects of dietary hesperidin supplementation on broiler performance and chicken meat characteristics. Can J Anim Sci 2011;91:275-82. https://doi.org/10.4141/cjas10094

[3] Williams P, Losa R. The use of essential oils and their compounds in poultry nutrition. World Poult 2001;17:14-5.

[4] Jang I, Ko Y, Yang H, Ha J, Kim J, Kang S, et al. Influence of essential oil components on growth performance and the functional activity of the pancreas and small intestine in broiler chickens. Asian-Australas J Anim Sci 2004;17:394-400. https://doi.org/10.5713/ajas.2004.394

[5] Lee K, Everts H, Kappert H, Wouterse H, Frehner M, Beynen A Cinnamaldehyde, but not thymol, counteracts the carboxymethyl celluloseinduced growth depression in female broiler chickens. Int J Poult Sci 2004;3:608-12. https://doi.org/10.3923/ijps.2004.608.612

[6] Lee K-W, Everts H, Kappert H, Frehner M, Losa R, Beynen A. Effects of dietary essential oil components on growth performance, digestive enzymes and lipid metabolism in female broiler chickens. Br Poult Sci 2003;44:450-7. https://doi.org/10.1080/0007166031000085508

[7] Pisoschi AM, Pop A. The role of antioxidants in the chemistry of oxidative stress: A review. Eur J Med Chem 2015;97:55-74. https://doi.org/10.1016/j.ejmech.2015.04.040

[8] Simitzis PE. Enrichment of animal diets with essential oils - a great perspective on improving animal performance and quality characteristics of the derived products. Medicines 2017;4:35. https://doi.org/10.3390/medicines4020035

[9] Zheng W, Wang SY. Antioxidant activity and phenolic compounds in selected herbs. J Agric Food Chem 2001;49:5165-70. https://doi.org/10.1021/jf010697n

[10] Bolukbasi S, Erhan MK. Effect of dietary thyme (Thymus vulgaris) on laying hens performance and Escherichia coli (E. coli) concentration in feces. IJNES. 2007.

[11] Cross D, McDevitt R, Hillman K, Acamovic T. The effect of herbs and their associated essential oils on performance, dietary digestibility and gut microflora in chickens from 7 to 28 days of age. Br Poult Sci 2007;48:496506. https://doi.org/10.1080/00071660701463221

[12] Al-Kassie GA. Influence of two plant extracts derived from thyme and cinnamon on broiler performance. Pak.vet j 2009;29:169-73.

[13] El-Ghousein SS, Al-Beitawi NA. The effect of feeding of crushed thyme (Thymus valgaris L) on growth, blood constituents, gastrointestinal tract and carcass characteristics of broiler chickens. J Poult Sci 2009;46:100-4. https://doi.org/10.2141/jpsa.46.100

[14] Najafi P, Torki M. Performance, Blood Metabolites and Immunocompetaence of Broiler. J Anim Vet Adv 2010;9:1164-8. https://doi.org/10.3923/javaa.2010.1164.1168

[15] Kim S-I, Yi J-H, Tak J-h, Ahn Y-J. Acaricidal activity of plant essential oils against Dermanyssus gallinae (Acari: Dermanyssidae). Vet Parasitol 2004;120:297-304. https://doi.org/10.1016/j.vetpar.2003.12.016

[16] Faix Š, Faixová Z, Plachá I, Koppel J. Effect of Cinnamomum zeylanicum essential oil on antioxidative status in broiler chickens. Acta Vet Brno 2009;78:411-7. https://doi.org/10.2754/avb200978030411

[17] Ferdandez-Botran' R GV, Sun XC, Ren, XP PG, Crespo FA, Oliver R, Orhu, HI $\mathrm{QE}$, Maldonado $\mathrm{C}$, Ray $\mathrm{M}$ and Barker, JH. Targeting of glycosaminoglycancytokine interactions as a novel therapeuticapproach in allotransplantation. Transplantation 2002; 74:623-9.

[18] Ebrahimi M, Hoseini A, Palizdar M, Mohamadian-Tabrizi H, Porelmi M. Effect of cinnamon, red pepper, ginger and cumin on broilers performance. Research Opinions in Animal and Veterinary Sciences 2013;3:131-5

[19] Park B-S. Effect of dietary cinnamon powder on savor and quality of chicken meat in broiler chickens. Korean J Food Nutr 2008;37:618-24. https://doi.org/10.3746/jkfn.2008.37.5.618

[20] Shirzadegan K. Reactions of modern broiler chickens to administration of cinnamon powder in the diet. Iran. J. Appl. AnimSci 2014;4:367-71.

[21] Ciftci M, Dalkilic B, Cerci I, Guler T, Ertas O, Arslan O. Influence of dietary cinnamon oil supplementation on performance and carcass characteristics in broilers. J. Appl Anim Res 2009;36:125-8. https://doi.org/10.1080/09712119.2009.9707045

[22] Sang-Oh P, Chae-Min R, Byung-Sung P, Jong $H$. The meat quality and growth performance in broiler chickens fed diet with cinnamon powder J environ biol 2013;34:127. 
[23] Eltazi SM. Effect of using ginger powder as natural feed additive on performance and carcass quality of broiler chicks. Assiut Vet Med J 2014;60:87-95.

[24] Wade M, Manwar S, Kuralkar S, Waghmare S, Ingle V, Hajare S. Effect of thyme essential oil on performance of broiler chicken. J Entomol Zool Stud 2018;6:25-8.

[25] Agostini P, Sola-Oriol D, Nofrarías M, Barroeta A, Gasa J, Manzanilla E. Role of in-feed clove supplementation on growth performance, intestinal microbiology, and morphology in broiler chicken. Livest Sci 2012;147:113-8. https://doi.org/10.1016/j.livsci.2012.04.010

[26] Ertas ON, Guler T, Çiftçi M, DalkIllç B, Simsek UG. The effect of an essential oil mix derived from oregano, clove and anise on broiler performance. Int J Poult Sci 2005;4:879-84. https://doi.org/10.3923/ijps.2005.879.884

[27] Isabel B, Santos Y. Effects of dietary organic acids and essential oils on growth performance and carcass characteristics of broiler chickens. J Appl Poult Res 2009;18:472-6. https://doi.org/10.3382/japr.200800096

[28] Azadegan Mehr M HA, Nasiri Moghaddam H., Kermanshahi $H$. Supplementation of clove essential oils and probiotic to the broiler's diet on performance, carcass traits and blood components. Iran J Appl.Anim Sci. 2014;4:117-22.

[29] Cabuk M, Alcicek A, Bozkurt M, Imre N. Antimicrobial properties of the essential oils isolated from aromatic plants and using possibility as alternative feed additives. National Animal Nutrition Congress. 2003. p. 18-20.

[30] Mukhtar MA. The effect of dietary clove oil on broiler performance. Aust j.basic appl sci 2011;5:49-51.

[31] Chang S-T, Chen P-F, Chang S-C. Antibacterial activity of leaf essential oils and their constituents from Cinnamomum osmophloeum. J Ethnopharmacol 2001;77:123-7. https://doi.org/10.1016/S03788741(01)00273-2

[32] Langhout P. New additives for broiler chickens. World poult 2000;16:22-7.

[33] Güler T, Ertas O, Ciftci M, Dalkilic B. The effect of coriander seed (Coriandrum sativum L.) as diet ingredient on the performance of Japanese quail. S Afr J Anim Sci 2005;35:261-7. https://doi.org/10.4314/sajas.v35i4.3969

[34] Demir E, Kilinc K, Yildirim Y, Dincer F, Eseceli H. Comparative effects of mint, sage, thyme and flavomycin in wheat-based broiler diets. Archiva Zootechnica 2008;11:54-63.

[35] Hernandez F, Madrid J, Garcia V, Orengo J, Megias M. Influence of two plant extracts on broilers performance, digestibility, and digestive organ size. Poult Sci 2004;83:169-74. https://doi.org/10.1093/ps/83.2.169

[36] Bampidis V, Christodoulou V, Florou-Paneri P, Christaki E, Chatzopoulou P, Tsiligianni $T$, et al. Effect of dietary dried oregano leaves on growth performance, carcase characteristics and serum cholesterol of female early maturing turkeys. Br Poult Sci 2005;46:595-601. https://doi.org/10.1080/00071660500256057

[37] Goldstein JL, Brown MS. Regulation of the mevalonate pathway. Nature 1990;343:425-30. https://doi.org/10.1038/343425a0.

[38] Mohammadi A, Oshaghi EA. Effect of garlic on lipid profile and expression of LXR alpha in intestine and liver of hypercholesterolemic mice. J
Diabetes Metabolic Disorders 2014;13:20. https://doi.org/10.1186/2251-6581-13-20

[39] Cornelius CE. Liver function. Clinical biochemistry of domestic animals: Elsevier; 1980. p. 201-57. https://doi.org/10.1016/B978-0-12-3963505.50011-5

[40] Attia YA, Bakhashwain AA, Bertu NK. Thyme oil (Thyme vulgaris L.) as a natural growth promoter for broiler chickens reared under hot climate. Ital. J Anim Sci 2017;16:275-82 https://doi.org/10.1080/1828051X.2016.1245594

[41] Elshafey A, Aziza, A., Orma, A., Mohamed, T. The effect of synthetic essential amino acids supplementation to low crude protein diets on growth performance and serum metabolites in broiler chickens. Mans $\begin{array}{llllll} & \text { Met } & 24 & \text { 20 } & \end{array}$ https://doi.org/10.35943/mvmj.2019.23.205

[42] Bento M, Ouwehand A, Tiihonen K, Lahtinen S, Nurminen P, Saarinen M, et al. Essential oils and their use in animal feeds for monogastric animals-Effects on feed quality, gut microbiota, growth performance and food safety: a review. Vet Med 2013;58.

[43] Krishan G, Narang A. Use of essential oils in poultry nutrition: A new approach. J Adv Vet Anim.Res 2014;1:156-62. https://doi.org/10.5455/javar.2014.a36

[44] Ciftci M, Simsek UG, Yuce A, Yilmaz O, Dalkilic B. Effects of dietary antibiotic and cinnamon oil supplementation on antioxidant enzyme activities, cholesterol levels and fatty acid compositions of serum and meat in broiler chickens. Acta Vet Brno 2010;79:33-40. https://doi.org/10.2754/avb201079010033

[45] Jayaprakasha G, Negi P, Jena B, Rao LJM. Antioxidant and antimutagenic activities of Cinnamomum zeylanicum fruit extracts. J Food Compos Anal 2007;20:330-6. https://doi.org/10.1016/j.jfca.2006.07.006

[46] Nieto G, Bañón S, Garrido MD. Effect of supplementing ewes' diet with thyme (Thymus zygis ssp. gracilis) leaves on the lipid oxidation of cooked lamb meat. Food Chem 2011;125:1147-52. https://doi.org/10.1016/j.foodchem.2010.09.090

[47] Gumus R, Ercan N, Imik H. The effect of thyme essential oil (Thymus vulgaris) added to quail diets on performance, some blood parameters, and the antioxidative metabolism of the serum and liver tissues. Braz J. Poult Sci 2017;19:297-304. https://doi.org/10.1590/1806-9061-20160403

[48] Fki I, Bouaziz M, Sahnoun Z, Sayadi S. Hypocholesterolemic effects of phenolic-rich extracts of Chemlali olive cultivar in rats fed a cholesterolrich diet. Bioorgan Med Chem 2005;13:5362-70. https://doi.org/10.1016/j.bmc.2005.05.036

[49] Hsu D-Z, Liu M-Y. Sesame oil protects against lipopolysaccharidestimulated oxidative stress in rats. Crit Care Med 2004;32:227-31. https://doi.org/10.1097/01.CCM.0000104947.16669.29

[50] Petrovic V, Marcincak S, Popelka P, Simkova J, Martonova M, Buleca J, et al. The effect of supplementation of clove and agrimony or clove and lemon balm on growth performance, antioxidant status and selected indices of lipid profile of broiler chickens. J Anim Physiol Anim Nutr 2012;96:970-7. https://doi.org/10.1111/j.1439-0396.2011.01207.x 